\title{
MUJER Y RELATO EN EL SIGLO XX: EL CASO DE VIRGINIA WOOLF
}

\author{
Laura María Lojo Rodríguez. Universidade de Santiago de Compostela
}

\begin{abstract}
El lenguaje de la alegoría y de la fábula surge en el siglo XX como reacción al realismo, el mismo movimiento que lo hizo desaparecer. En una tradición narrativa que algunos críticos consideran afín o incluso coincidente, la alegoría y la fábula tendrían su continuación como género en el relato, que se aleja de la representación directa de la realidad superficial y más aparente para presentar la ética de una fantasía controlada, pero que, a pesar de ello, es muy cercana a la experiencia humana real. La finalidad del presente ensayo es tratar de desarrollar dos cuestiones fundamentales a este respecto: por un lado, cómo en los albores del siglo XX el relato moderno de mujeres supone un ejercicio de resistencia frente al género de la novela; por otro, redescubrir la figura de la escritora británica Virginia Woolf desde esta perspectiva y a través de las metáforas emancipadoras que subyacen a "The mark on the wall" (1917).
\end{abstract}

El lenguaje de la alegoría y de la fábula - suplantados una vez por el realismo, que barajaba términos como "objetividad", "distancia" y "experimentación" - surgen en el siglo $\mathrm{XX}$ como reacción al mismo movimiento que le hizo desaparecer: el realismo y el positivismo. En una tradición narrativa que algunos críticos consideran afín o incluso coincidente (Shaw, 1983: vii), la alegoría y la fábula tendrían su continuación como género en el relato. Robert Scholes (1979: 3) fue uno de los primeros críticos en analizar este fenómeno, al que denominó "fabulación". La palabra está obviamente asociada a "fábula", que nos sugiere el arte de la literatura didáctica y ejemplarizante, pero también recuerda a las fábulas de Esopo, que se alejan de la representación directa de la realidad superficial y más aparente para presentar la ética de una fantasía controlada, pero que, a pesar de ello, es muy cercana a la experiencia humana real.

A menudo la crítica feminista ha estudiado la utilización de la fábula y el arquetipo como elemento configurador esencial de la literatura de mujeres, especialmente en la segunda mitad del siglo XX, y a través de la narrativa de autoras como Angela Carter, Muriel Spark o Fay Weldon, y, en especial, sus relatos como una reescritura del cuento de hadas 
tradicional. ${ }^{1}$ Pero en esta corriente resulta del todo vital la elección del género, esto es, de la narrativa breve como método para reescribir, reformular o incluso subvertir la realidad.

La finalidad del presente ensayo es tratar de desarrollar dos cuestiones fundamentales a este respecto: por un lado, analizar cómo el relato moderno, surgido a principios del siglo $\mathrm{XX}$, supone un ejercicio de resistencia frente al género de la novela, dominado entonces por la técnica del realismo burgués que, en ese momento, ya había agotado sus posibilidades estéticas. El relato se convierte en vehículo adecuado para la experimentación, rechazando nociones como causalidad, historicismo o moralidad, y resulta interesante comprobar cómo toda una tradición de mujeres escritoras lo escogen como forma de expresión literaria al cuestionar éste los modos realistas de escritura y, por tanto, nociones como coherencia, orden y verdad.

Una segunda parte de este ensayo pretende redescubrir la figura de la escritora británica Virginia Woolf (1882-1941) desde la perspectiva del relato, dimensión en la que resulta poco conocida en relación con su faceta como novelista, pero que es crucial para su desarrollo como escritora profesional. El análisis se centrará en las metáforas emancipadoras que subyacen a la primera publicación de Hogarth Press - editorial fundada por Leonard y Virginia Woolf en 1917 - y que es, de manera significativa, un relato titulado "The mark on the wall" (1917), a su vez sinónimo de emancipación editorial, literaria e ideológica de la propia Woolf.

Resulta del todo revelador el hecho de que Virginia Woolf considere dicho género especialmente adecuado para expresar sus nuevas inquietudes estéticas a la vez que define su propia forma de resistencia al realismo decimonónico que, en los años del cambio al siglo $\mathrm{XX}$, aparecía encarnado en la novela. Woolf se expresa del siguiente modo con motivo de su primer relato publicado - "The mark on the wall" (1917) - que también fue la primera publicación de la editorial que ella y su marido Leonard fundaron: "In a way, it is easier to do a short thing, all in one flight than a novel. Novels are frightfully clumsy and overpowering of course ... I daresay one ought to invent a completely new form" (1994b: 167).

En este sentido, Woolf se suma a una larga lista de escritores modernistas - James Joyce, E. M. Forster, D. H. Lawrence, Katherine Mansfield, Wyndham Lewis or Malcolm Lowry - que escogieron el género del relato para dar un giro a su obra, porque vieron en él el vehículo adecuado para plasmar la necesidad de renovar el arte de la ficción. Tal y como arguye Dominic Head (1992: 1), el nacimiento del relato moderno en las dos últimas décadas del siglo XIX coincide cronológicamente con la emergencia del modernismo como movimiento artístico. Y esto sucede así porque el género de la novela tal y como se había entendido a finales del siglo XIX había agotado ya sus posibilidades estéticas. ${ }^{2}$

Como sostiene Wendell Harris (1994: 183), tras Henry Fielding se impone el modelo de historia contemporánea para la novela que se prolongaría hasta bien entrado el siglo XX. La narrativa histórica presenta al individuo a lo largo de un continuo temporal, a la vez que

\footnotetext{
${ }^{1}$ A este respecto ver, por ejemplo, Marina Warner, From the Beast to the Blonde: On Fairy Tales and Their Tellers (London: Chatto \& Windus, 1995) y Cristina Bacchilega, Postmodern Fairy Tales: Gender and Narrative Strategies (Philadelphia: U of Pennsylvania P, 1996).

2 Para un desarrollo de estas cuestiones, ver Georg Lukács, The Theory of the Novel: A HistoricoPhilosophical Essay on the Forms of the Great Epic Literature (Anna Bostock trad. Cambridge, Massachusetts: MIT Press, 1971); Suzanne Ferguson, "The rise of the short story in the hierarchy of genres" en Short Story Theory at a Crossroads (Susan Lohafer \& Jo Ellyn Clarey eds. Baton Rouge \& London: Louisiana State University Press, 1989: 176-192); Dean Baldwin, "The tardy evolution of the British short story" en Studies in Short Fiction 30 (1993: 23-33) y Wendell Harris, "Vision and Form: The English novel and the emergence of the short story" en The New Short Story Theories (Charles May ed. Athens, Ohio: Ohio University Press, 1994: 182-191).
}

Odisea, $n^{\circ} 2,2002$ 
muestra la interacción y relaciones de éste con una sociedad y momento histórico concreto: se convertía en la fuerza creadora del individuo y de la historia colectiva (Watt, 1957: 22). El nacimiento de la novela como género no sólo coincide con una forma autoconsciente de concebir la historia, sino también con una emergente clase media, la burguesía, que deseaba ver su prestigio reproducido en el arte y que se apropió del género como suyo. La novela floreció de modo espectacular durante el siglo XIX: la conciencia histórica se traducía en la narrativa en el énfasis en la cadena de la causalidad, en presentar el conjunto de relaciones del individuo con la sociedad y a través del tiempo, todo ello apoyado por los comentarios - más o menos explícitos - de la voz autorial que especulaba acerca del significado de la sociedad, la moral y la historia. En resumen, la novela victoriana se centraba en la interacción del individuo con las presiones socioeconómicas del mundo en que vivía, presentando como "efecto" las elecciones del propio individuo.

Tal fue la popularidad de la novela en la época victoriana, que el término "narrativa" parecía abarcar solamente el género de la novela, y eclipsar todos los demás, especialmente en Inglaterra: hacia la segunda mitad del siglo XIX, la novela histórica comienza a perder fuerza, y surge el relato moderno - fuertemente ligado a la demanda ofertada por la floreciente industria de la prensa periódica - en los Estados Unidos, Francia, Alemania y, especialmente, Rusia. En Inglaterra, sin embargo, el nacimiento del relato moderno no tendrá lugar hasta finales del siglo XIX, dado el enorme impacto social e ideológico de la novela: los relatos existentes, en su mayoría pertenecientes a novelistas como Charles Dickens, Anthony Trollope o Thomas Hardy, simplemente condensaban en miniaturas los elementos de sus novelas en una visión totalmente inadecuada.

Por tanto, podría decirse que el relato moderno nace como reacción al positivismo e historicismo de la novela victoriana; frente a ésta, el relato se desmarca del continuo histórico y social para aislar, retratar el momento y el individuo concreto. El relato, como señalaría Frank O'Connor, se convierte en la expresión de libertad estética y personal para el individuo en desacuerdo con la sociedad convencional y con la expresión artística de la moral burguesa: "The novel can still adhere to the classical concept of a civilised society, of man as an animal who lives in a community ... but the short story remains by its very nature remote from the community - romantic, individualistic, intransigent" (1963: 21).

Curiosamente, el género del relato ha sido desde su nacimiento acogido por las mujeres como vehículo de expresión adecuado para ofrecer su experiencia periférica. Clare Hanson (1989: 3) ha señalado cómo la generación de la "New Woman" tomó el relato como género literario preferente: escritoras como Ella D’Arcy, Evelyn Sharp o George Egerton explotaron el potencial de la forma para explorar la experiencia femenina. En un ensayo de 1916 titulado "Hours in a Library", Virginia Woolf expresa la situación en los siguientes términos: "No age of literature is so little submissive to authority as ours, so free from the dominion of the great; none seems so wayward with its gift of reverence, or so volatile in its experiments" (1987: 59). Woolf alude al espíritu contestatario y de rebeldía que caracteriza a su generación de escritores, que se distancian de sus predecesores más inmediatos en la busca de nuevas formas estéticas que sean acordes con su nueva experiencia: "Did we ever in our youngest days feel such amazement at their ['the classics'] achievement as that which fills us now that we have shifted myriads of words and gone along uncharted ways in search of new forms for our new sensations?" (1987: 60).

Y las "nuevas formas" para las también nuevas "sensaciones" inevitablemente pasa por abandonar la tradición narrativa decimonónica de capítulos y abrir caminos todavía inexplorados. De hecho, cierto sector de la crítica feminista cuestiona seriamente los modos realistas de escritura: la búsqueda del orden, la coherencia y la verdad absoluta que

Odisea, $\mathrm{n}^{\circ} 2,2002$ 
subyace al realismo es un modo de minimizar el orden simbólico. ${ }^{3}$ La ausencia del realismo en la escritura, como señala Mary Eagleton (1989: 58), permitiría a las mujeres la expresión de contradicciones, fantasías y deseos que el realismo silencia. Virginia Woolf lo expresa del siguiente modo: "Let us say what comes into our heads, repeat ourselves, contradict ourselves, fling out the wildest nonsense, and follow the most fantastic fancies without caring what the world does or thinks or says" (1994a: 63).

En A Room of One's Own (1929), Virginia Woolf se pregunta si existe una conexión entre sexo y género al contemplar las estanterías de una biblioteca correspondientes al siglo XIX: "Here, then, one had reached the early nineteenth century. And there, for the first time, I found shelves given up entirely to the works of women. But why, I could not help asking, as I ran my eyes over them, were they, with very few exceptions, all novels?" (1992: 66-67). El proceso de escritura de una novela es, al contrario que otras profesiones, una forma de producción doméstica en el que la mujer podría evitar todo contacto con la esfera pública, e incluso utilizar un seudónimo. Woolf lo pone de manifiesto hablando de Jane Austen: "She was careful that her occupation should not be suspected by servants or visitors or any persons beyond the family party. Jane Austen hid her manuscripts or covered them with a piece of blotting paper" (1992: 67).

En "Professions for Women" (1931), uno de sus ensayos más celebrados y dirigido precisamente a una asociación de mujeres trabajadoras, Virginia Woolf duda de que la etiqueta de "profesionalización" pueda ser aplicada con rigor al arte de la literatura: "It is true that I am a woman; it is true I am employed; but what professional experiences have I had?" (1993: 101). Al contrario que el desarrollo de otras profesiones, la práctica de la literatura no suponía una ocupación peligrosa para la moral femenina ni un desembolso pecuniario por parte de esos padres de familia que sin duda preferían reservarlo para la educación de sus hijos varones: "Thus, when I came to write, there were few material obstacles in my way. Writing was a reputable and harmless occupation. The family peace was not broken by the scratching of a pen. No demand was made upon the family purse" (1993: 101). Sin duda, los problemas de Woolf con la escritura son de cariz muy distinto como ella misma apunta en este revelador ensayo - y se refieren más bien al entorno patriarcal que domina la esfera pública de, en este caso, la vida literaria. Al constreñido espíritu crítico que cualquier mujer escritora se vería obligada a ocultar en aras de un supuesto ideal de pureza típicamente victoriano le denomina Woolf "the Angel in the House": 4

For, as I found, directly I put pen to paper, you cannot review even a novel without having a mind of your own, without expressing what you think to be the truth about human relations, morality, sex. And all these questions, according to the Angel of the House, cannot be dealt with freely and openly by women; they must - to put it bluntly - tell lies if they are to succeed. (Woolf, 1993: 103)

\footnotetext{
${ }^{3}$ A este respecto, ver Cheryl Brown y Karen Olson eds., Feminist Criticism: Essays on Theory, Poetry and Prose (New Jersey y Londres: The Scarecrow P, 1978); Carolyn Heilbrun y Margaret Higonnet eds., The Representation of Women in Fiction (Baltimore y Londres: The John Hopkins UP, 1983); Ellen Moers, Literary Women (Londres: The Women's P, 1978) y Rosemary Jackson, Fantasy: The Literature of Subversion (Londres: Methuen, 1981).

4 "The Angel in the House" es el título de un poema del escritor victoriano Coventry Patmore (18231896), en el que se idealiza el papel doméstico de la mujer a la vez que se ensalzan virtudes consideradas como típicamente femeninas, a saber, la pureza, dulzura, sumisión y abnegación, encarnadas principalmente en la figura de esposa y madre de familia.
}

Odisea, $n^{\circ} 2,2002$ 
Como ella misma admite, exterminar al "ángel de la casa" - o, en otras palabras, a la rémora del espíritu moral decimonónico - formaba parte de los requisitos para poder convertirse en artista, y es lo que Woolf denomina la primera de las dos experiencias o aventuras genuinas de su vida profesional. La segunda - mucho más difícil de acometer y que de hecho Woolf confiesa no haber podido superar en un grado satisfactorio - es lo que se refiere precisamente a su sexo, a su experiencia como mujer: "But the second [adventure], telling the truth about my own experiences as a body, I do not think I solved" (1993: 105).

Para Woolf es evidente que la novela como género aparece íntimamente ligada a una clase media burguesa, que las consume y también las produce, como explica en $A$ Room of One's Own: "Yet by some strange force they were all compelled, when they wrote, to write novels. Had it something to do with being born of the middle class?" (1992: 67). La vida del salón de té que la mujer del siglo XIX tan bien conocía configura la temática de la novela lo que, según Woolf, explica la proliferación de mujeres novelistas en este momento:

Then, again, all the literary training that a woman had in the early nineteenth century was training in the observation of character, in the analysis of emotion. Her sensibility had been educated for centuries by the influences of the common sitting room ... Therefore, when the middle-class woman took to writing, she naturally wrote novels. (1992: 67-68)

Quizás esto explique el porqué de la elección del relato como género - no sólo por Woolf, sino también por otras muchas mujeres escritoras - para expresar su resistencia al perenne realismo burgués de la novela de principios del siglo XX y que les permitiría, por tanto, explorar las profundidades del inconsciente, tal y como lo describe en "Professions for Women":

She was letting her imagination sweep unchecked round every rock and cranny of the world that lies submerged in the depths of our unconscious being. Now came the experience, the experience that I believe to be far commoner with women writers than with men. The line raced through the girl's fingers. Her imagination had rushed away. It had sought the pools, the depths, the dark places where the largest fish slumber. (Woolf, 1993: 104)

Sin embargo, la asunción de que la narrativa breve es un género marginal - con respecto a lo "central" de la novela - y por ello especialmente adecuado como medio de expresión para las mujeres, también en la periferia, corre el riesgo de encapsular más si cabe la producción de relatos de mujeres. Como ha señalado Hermione Lee: "There is no value in suggesting that women writers are better suited to the short story form than men" (1995: x). Es cierto que el relato moderno cuestiona la autoridad social y literaria, los estereotipos sexuales y el realismo como método, pero éstas no son actitudes exclusivamente femeninas, sino más bien pertenecientes a lo que ha dado en llamarse "modernidad". Esto no niega la evidencia, sin embargo, de que los relatos de mujeres están plagados de imágenes y lenguaje emancipador - sin duda reflejo de los movimientos de liberación de la mujer de principios del siglo XX - que no sólo ha de entenderse en sentido social, sino también estético y literario, lo que Woolf definía como "the masculine point of view which governs our lives" (1985: 86) en "The mark on the wall", el primer relato con el que "transgredió" la estética realista. 
En 1936, Elizabeth Bowen escribiría un influyente ensayo acerca de la naturaleza formal del relato moderno y destacando, sobre todo, la libertad del género frente a la rigidez de la novela. Bowen define el relato, junto con el cine, como invención del siglo XX y, por tanto, libre de las constricciones de una tradición literaria $\mathrm{y}$, especialmente, de la novela, enfatizando, sobre todo, la libertad formal que para el escritor supone la práctica de éste. Bowen contempla el relato como una bocanada de aire fresco en el género narrativo; el realismo, el discurso racionalista y la exhaustividad histórica que se traducía en un número interminable de páginas habían acabado por agotar la novela:

In England, the limitations of narrative prose with its longueurs, its conventions dangerous to truth, had appeared for a long time to be impassable: oblique narration, cutting (as in the cinema), the unlikely placing of emphasis, or symbolism (the telling use of the object both for its own sake and as image) were unknown. (Bowen, 1976: 153)

Eudora Welty hace hincapié en una idea similar; la novedad que supone el relato frente al anquilosamiento de la novela: "Stories are new things, stories make words new; that is one of the illusions and part of their beauty" (Welty, 1949: 159). Nadine Gordimer resumiría años más tarde las razones por las que el escritor moderno consideraba el relato un género tan sugerente. Para Gordimer, la decadencia de la novela se debe a que el método de ésta para plasmar la realidad es igualmente obsoleto; por el contrario, el relato - liberado de la poderosísima tradición prescriptiva de la novela - se muestra mucho más flexible y abierto a la innovación: "Certainly the short story always has been more flexible and open to experiment than the novel" (Gordimer, 1968: 179).

Curiosamente, todas estas mujeres apuntan dos ideas básicas en las que coinciden: por un lado, la visión del relato moderno como una expresión de libertad para el escritor, no tanto en cuestión formal - si cabe, incluso más compleja que la de la novela - como en el método elegido para describir la realidad. Por otro, e íntimamente ligado con el punto anterior, las convenciones estéticas y formales de la novela son, para todas ellas, inadecuadas e incluso "peligrosas" para presentar la "verdad" o, en otras palabras, la esencia de la naturaleza humana: "The strongest convention of the novel, prolonged coherence of tone, to which even the most experimental of novels must conform unless it is to fall apart, is false to the nature of whatever can be grasped of human reality" (Gordimer, 1968: 179).

Por otro lado, el auge de la industria editorial periódica - íntimamente ligado al nacimiento, desarrollo y consolidación del relato moderno - permitió a las mujeres abrirse un hueco entre sus páginas, publicando tanto reflexiones teóricas como literatura de creación, fundamentalmente poesía y relato: ${ }^{5}$ en 1911, Dora Marsden funda The New Freewoman que, bajo los auspicios de Harriet Shaw Weaver, pasaría a llamarse The Egoist en 1914 en Londres; Harriet Monroe funda Poetry en 1912 en Chicago y Margaret Anderson Little Review en 1914. Y todo ello sólo fue el inicio de una larga serie de publicaciones periódicas a ambos lados del Atlántico, que permitió una interacción tanto personal como profesional entre mujeres escritoras que se editaban, comentaban e imitaban unas a otras.

Pero sin duda alguna, Virginia Woolf se convertiría en uno de los nombres claves durante la primera mitad del siglo XX relacionados con este tipo de actividad al que ella dedicó gran parte de su vida y esfuerzos. En parte, la historia de la editorial que Virginia y

\footnotetext{
${ }^{5}$ Para un desarrollo de este punto, ver Gillian Hanscombe y Virginia Smyers, Writing for Their Lives: The Modernist Women 1910-1940 (Londres: The Women's Press, 1987).
}

Odisea, $\mathrm{n}^{\mathrm{0}} 2,2002$ 
Leonard Woolf fundaron en 1917 - Hogarth Press - es también la historia del proceso de maduración y consolidación de Virginia Woolf como escritora profesional, comprometida a la vez con las corrientes culturales europeas, como mostrarían las publicaciones en su editorial. En términos generales, tanto Leonard como Virginia hacen hincapié en el hecho de que una de las grandes razones que les impulsaron a la creación de Hogarth Press sería la publicación de pequeños libros y panfletos o de aquellos trabajos que, por una razón u otra, no habían interesado a las editoriales comerciales. ${ }^{6}$ Ninguno de ellos podía imaginarse que el pequeño negocio familiar se convertiría en uno de los instrumentos estéticos e ideológicos más relevantes de Inglaterra, publicando obras emblemáticas para el desarrollo del arte y del pensamiento europeo durante la primera mitad del siglo XX. Las futuras publicaciones de Hogarth Press tenían un carácter heterogéneo, abarcando poesía, literatura de creación, crítica literaria, arte, historia, psicoanálisis, política o economía, que colocaron a Bloomsbury en una posición central en la vida intelectual y cultural del momento. $^{7}$

Todo ello se conjuga en las circunstancias personales y profesionales de Woolf en el año 1917 y que hicieron posible la existencia del primero de una serie de relatos en el que Woolf se aleja, con confianza y por primera vez, de las convenciones realistas que había utilizado en su primera novela, The Voyage Out (1915). "The mark on the wall" supone el reflejo de la expresión de libertad artística, que se plasma en lo que anteriormente hemos denominado lenguaje e imágenes emancipadoras. Fue la primera publicación de Hogarth Press, y apareció en un pequeño volumen titulado Two Stories, que contenía además, como su nombre indica, el relato de Leonard Woolf "Three Jews".Tras la publicación de "The mark on the wall", Virginia Woolf escribe a David Garnett explicándole lo que para ella ha supuesto el proceso de composición y edición de este relato: "I'm very glad you liked the story ... it's the greatest mercy to be able to do what one likes - no editors, no publishers, and only people to read who more or less like that sort of thing" (1976a: 167). De nuevo, el pasaje está plagado de imágenes de libertad, en las que Woolf subraya la importancia de la experimentación en su nuevo trabajo, que sólo ha sido posible gracias a la ausencia de la figura del editor, aun a riesgo de que la obra alcance una difusión menor.

Efectivamente, "The mark on the wall" es el primero de una serie de relatos que culminarían en 1921 con la compilación titulada Monday or Tuesday, y que suponen un giro radical en el modo de concebir la literatura para Woolf. Aquí utiliza Woolf por primera vez el llamado stream-of-consciousness con el que pretende dar relevancia y profundidad a su descripción de la mente humana y de los mecanismos por los que ésta se rige. La propia Virginia Woolf concede especial importancia a los relatos compuestos entre estos años, porque suponen el descubrimiento y puesta en práctica de un nuevo método de aproximación a la realidad literaria: "Conceive mark on the wall, K[ew] G[ardens] \& unwritten

\footnotetext{
${ }^{6}$ Un excelente estudio sobre la historia de Hogarth Press es el trabajo de J. H. Willis, Leonard and Virginia Woolf as Publishers: The Hogarth Press 1917-1941 (Charlottesville \& Londres: University Press of Virginia, 1992). Para un análisis de la naturaleza de las publicaciones de Leonard y Virginia Woolf en Hogarth Press, ver Laura Marcus, "Virginia Woolf and the Hogarth Press" en Modernist Writers and the Marketplace (Ian Willison et al. eds., Londres: McMillan, 1996: 124-150).

7 Tal y como ha señalado Laura Marcus (1996: 129), las contribuciones a la vida cultural e intelectual de Hogarth Press engloban tres dimensiones fundamentales: la publicación de panfletos sobre debates culturales y políticos específicos (estética, feminismo, pacifismo, anti-imperialismo, comunismo); la publicación de obras poéticas, especialmente en la década de los años 30, cuando el poeta John Lehman era el encargado de Hogarth; la publicación de la obra psicoanalítica de Sigmund Freud, que durante años fueron las únicas ediciones disponibles en inglés.
}

Odisea, $\mathrm{n}^{\mathrm{o}} 2, \quad 2002$ 
novel taking hands and dancing in unity. What the unity shall be I have yet to discover: the theme is a blank to me; but I see immense possibilities in the form" (1978: 13). A los ojos de Woolf, difícilmente hubieran estos relatos encontrado un editor comercial: "What I owe the Hogarth Press is barely paid for by the whole of my handwriting ... I'm the only woman in England free to write what I like ... the others must be thinking of series and editors" (1980: 42-3). ${ }^{8}$

Muchos años más tarde, cuando Virginia Woolf se había convertido en una escritora leída y respetada, recuerda los primeros años de Hogarth Press que, para ella, aparecen íntimamente relacionados con la composición de los relatos que compondrían la colección Monday or Tuesday y, especialmente, con "The mark on the wall", el primero de todos ellos: "I shall never forget the day I wrote The Mark on the Wall - all in a flash, as if flying, after being stone breaking for months. That - again in one second - showed me how I could embody all my deposit of experience in a shape that fitted it" (1994b: 231).

Efectivamente, "The mark on the wall" fue el primero de todos estos relatos y, sin duda, el que hizo posible que Woolf continuase en dicha línea de escritura, tras las alabanzas de sus amigos y familiares y la aprobación de la crítica. Desde un punto de vista técnico, el relato se aleja de lo que Woolf denominaba "the intricacy of plot" (1987: 77) para profundizar en los pensamientos aparentemente enredados, incoherentes y deslavazados de un narrador anónimo femenino que se deleita en ellos. Pero a pesar de lo que pudiera parecer, "The Mark on the Wall" no responde a una narrativa oscura o solipsista; lo que resulta más significativo de todo ello es, sin duda, el empleo de imágenes emancipadoras que subrayan la necesidad, no sólo de la narradora anónima en particular, sino de las mujeres en general, de liberarse de las constricciones de un orden social patriarcal en el que dominan las imágenes de opresión, algunas de las cuales Woolf utilizará más tarde en A Room of One's Own. Y esta línea de resistencia al orden monológico patriarcal que se desprende tanto del contenido como de la forma - fluida y alejada del orden, la coherencia y la causalidad realistas - que encarnan dichas imágenes es el hilván ideológico de "The mark on the wall".

La estructura del relato parte de la alusión por parte de este narrador - en principio anónimo - a la "marca en la pared", que ofrece el título a la narración y que además despliega una serie de imágenes asociadas a ésta. Efectivamente, "the mark on the wall" es el punto de partida desde el cual arrancan los pensamientos encadenados del narrador, quien se pregunta acerca de la naturaleza y origen de esa mancha negruzca en la pared. Lo que en principio podría parecer una sucesión de hipótesis más o menos relevantes acerca de la mancha, se convierte sin embargo en todo un alegato ideológico en donde Woolf vierte - no sin la sutil ironía que la caracteriza - una crítica al patriarcado y a su política de exclusión hacia las mujeres.

Woolf utilizará la misma imagen - la "marca en la pared" - muchos años más tarde en uno de sus ensayos feministas más conocidos, A Room of One's Own (1929), y resulta clarificador, a este respecto, el comentario de otro narrador anónimo femenino en dicha obra:

\footnotetext{
${ }_{8}$ En muchos aspectos, Hogarth Press se convirtió para Virginia Woolf en sinónimo de una "habitación propia", de esa independencia económica que apuntaría más tarde en A Room of One’s Own (1929) como condición esencial para el desarrollo artístico. Los beneficios que la editorial le reportaba, sumado a la libertad que a la hora de escribir Woolf poseía, le permitieron explorar nuevas formas literarias. La expansión de Hogarth Press y el desarrollo literario de Woolf son fenómenos interdependientes que, a la vez, aparecen relacionados con los relatos de la colección Monday or Tuesday (1921) - "The mark on the wall" entre ellos - que Leonard Woolf describió como "a microcosm of all her then unwritten novels" (1964: 240).
}

Odisea, $n^{\circ} 2,2002$ 
"There is no mark on the wall to measure the precise height of women. There are no yard measures, neatly divided into the fractions of an inch, that one can lay against the qualities of a good mother, or the fidelity of a sister, or the capacity of a housekeeper" (Woolf, 1992: 111). Puesto que, hasta el momento, la historia se compone de una sucesión de grandes acontecimientos que sólo tienen lugar en la esfera pública, las mujeres están ausentes en su escritura y no son partícipes de ninguno de sus grandes logros, relegadas al anonimato de la vida privada: "Few women even now have been graded at the universities; the great trials of the professions, army and navy, trade, politics and diplomacy have hardly tested them. They remain even at this moment unclassified" (1992: 111). La mancha oscura que el narrador observa en la pared de su habitación - que a la vez recuerda la privacidad metafórica de la descrita en A Room of One's Own - le lleva sin duda y de manera "inconsciente" a medir los obstáculos que, como mujer, le impiden alcanzar una marca en la pared.

Sí que hubiera podido alcanzar esa marca el posible retrato que el narrador imagina colgó en su pared tiempo atrás, y que pertenecería a los anteriores dueños de la casa: "The miniature of a lady with white powdered curls, powder-dusted cheeks, and lips like red carnations" (1985: 83). El narrador ridiculiza de manera clara las convenciones pictóricas de este tipo de representaciones artísticas pertenecientes a un realismo obsoleto. ${ }^{9}$ Por otra parte, la tradición del retrato - fuertemente arraigada en las Islas Británicas y que disfrutaría en la época victoriana de gran popularidad - subraya la idea de la genealogía como característica esencial de identificación, idea que se repetirá en el relato más adelante, a través de la imagen del Almanaque de Whitaker. Como ha señalado Diane Gillespie (1988: 205), para algunos personajes de la obra de Woolf, el retrato parece estar asociado a la intimidad e identidad familiar, pero también a conceptos como tradición y autoridad, de tal forma que los retratos ayudan a caracterizar a aquellos que los poseen. ${ }^{10}$ En este caso, sin duda el retrato de la dama afectada apunta, por un lado, a la moda de los nuevos ricos por retratarse en lo que era un símbolo de poder económico, pero también sería un modo de garantizar la continuidad de los valores de una determinada clase y de una determinada época, a los que el narrador se enfrenta a lo largo de todo el relato, conjurando su posible efecto ideológico y calificándolo de "fraude": "A fraud of course, for the people who had this house before us would have chosen pictures in that way - an old picture for an old room" (Woolf, 1985: 83).

La herencia de valores victorianos se refleja también en objetos cotidianos que el narrador se esfuerza por descartar de su vida y entorno como algo inútil y obsoleto: "Then there were the bird cages, the iron hoops, the steel skates, the Queen Anne coal-scuttle, the bagatelle board, the hand organ - all gone, and jewels too ... What a scraping paring affair it is to be sure!" (1985: 84). Pero frente a la aparente solidez y rigidez de una sociedad y unos

\footnotetext{
9 En "The Royal Academy" (1919) Woolf ofrece de nuevo una visión satírica de la tradición retratista inglesa, así como las instituciones que seguían alentando este tipo de representaciones pictóricas: "We find ourselves confronted by a lady in full evening dress. She stands at the top of the staircase, one hand loosely closed around a sheaf of lilies, while the other is about to greet someone of distinction who advances towards her up the stairs. Not a hair out of place. Her lips are just parted. She is about to say, 'How nice of you to come!' But such is the skill of the artist that one does not willingly cross the range of her cordial and condescending eye" (Woolf, 1988: 89).

${ }^{10}$ Para un interesante estudio de la importancia del retrato en la obra de Virginia Woolf, ver Dennis Denisoff, "The forest beyond the frame: picturing women's desire in Vernon Lee and Virginia Woolf" en Women and British Aestheticism, Talia Schaffer \& Kathy Alexis Psomiades eds. (Charlottesville \& London: U of Virginia P., 1999: 251-269).
} 
valores que antaño parecían inamovibles, el narrador femenino de este relato propone sumergirse en la vorágine de la vida moderna, en constante cambio y movimiento, como enfatiza la imagen del vértigo producido por la velocidad del metro: ${ }^{11}$

If one wants to compare life to anything, one must liken it to being blown through the Tube at fifty miles an hour - landing at the other end without a single hairpin in one's hair! Shot out at the feet of God entirely naked! Tumbling head over heels in the asphodel meadows like brown paper parcels pitched down a shoot in the post office! With one's hair flying back like the tail of a racehorse. Yes, that seems to express the rapidity of life, the perpetual waste and repair; all so casual, all so haphazard ... (1985: 84)

La rapidez vertiginosa con la que fluye la vida contrasta con las imágenes estáticas, de rigidez y estancamiento que utiliza el narrador para describir la solidez y rectitud inflexibles de la sociedad patriarcal, en la que "hay una regla para todo" (1985: 86). Dichas reglas, que regulan la existencia humana, sus hábitos de conducta e incluso el conocimiento, son especialmente agresivas y opresoras para las mujeres: "Men perhaps, should you be a woman; the masculine point of view which governs our lives, which sets the standard, which establishes Whitaker's Table of Precedency" (1985: 87). La alusión a este almanaque se convierte en un aspecto central en el relato, pues subraya la política de exclusión que caracteriza al patriarcado: se trata éste de una publicación anual que establece el orden social conforme a un determinado rango, comenzando por la familia real y continuando en escalafón por las figuras gubernamentales y religiosas más relevantes. Y de nuevo - en su alegato pacifista y feminista más conocido, Three Guineas (1938) - Woolf utilizará la alusión al almanaque de Whitaker para constatar la evidente ausencia de las mujeres en el mismo. El almanaque de Whitaker, además, se convierte aquí en metáfora del patrón masculino que excluye a las mujeres de la vida pública y de una sociedad en la que "the great thing is to know who follows whom" (Woolf, 1985: 88).

El narrador femenino propone una posición de resistencia frente al orden patriarcal establecido, que proporciona "an intoxicating sense of illegitimate freedom - if freedom exists ..." (1985: 86). Tal libertad se disfruta en un mundo "tranquilo y espacioso", un jardín edénico del que están ausentes las figuras de autoridad en el que el narrador se sumerge:

Yes, one could imagine a very pleasant world. A quiet spacious world, with the flowers so red and blue in the open fields. A world without professors or specialists or house-keepers with the profiles of policemen, a world which one could slice with one's thought as a fish slices the water with his fin, grazing the stems of the waterlilies, hanging suspended over nests of white sea eggs ... How peaceful it is down there, rooted in the centre of the world and gazing up through grey waters, with their sudden gleams of light, and their reflections ... (1985: 87-88)

\footnotetext{
${ }^{11}$ El énfasis woolfiano en la experiencia - por definición cambiante y fluida - y en la vida como arte debe mucho al movimiento esteticista inglés y, sobre todo, a la influencia de uno de sus mayores exponentes, Walter Pater. En la conclusión a su conocido ensayo The Renaissance (1873), Pater enfatiza la belleza de la vida física, a la que describe en unos términos que recuerdan a los que utilizará la propia Woolf en "The mark on the wall": "Our physical life is a perpetual motion ... - the passage of the blood, the waste and repairing of the lenses of the eye, the modification of the tissues of the brain under every ray of light and sound - processes which science reduces to simpler and more elementary forces" (Pater, 1986: 150).
}

Odisea, $n^{\circ} 2,2002$ 
Las imágenes relacionadas con el agua y el jardín sugieren el inicio de la vida, de la propia existencia, que Woolf describirá en términos muy similares hacia el final de su vida en su autobiografía "A Sketch of the Past" (1939), en el regazo de su madre mientras escuchaba el rítmico sonido del devalar marítimo: "I begin: the first memory. This was of red and purple flowers on a black ground - my mother's dress ... and of hearing the waves breaking, one, two, one, two, and sending a splash of water over the beach" (1976b: 64). Frente al rechazo, la exclusión y la rigidez del orden patriarcal, el narrador sugiere la existencia de un lugar paradisíaco y comunal sinónimo de libertad, ausente de reglas y constricciones, abierto y espacioso que, por otra parte, recuerda a las metáforas que Woolf utiliza - entre ellas la ya vista en "Professions for Women" - para referirse al funcionamiento de la mente humana.

Pero reflejar el aparente caos e incoherencia del inconsciente también requiere, como Woolf sabía bien, un cierto grado de libertad literaria y de la ausencia de ciertas convenciones que podrían oprimir tal representación, como las de la "ficción histórica" con la que el narrador confiesa aburrirse (Woolf, 1985: 85). En su lugar, este narrador propone una nueva aproximación al arte de la literatura, en la que se deje a un lado la descripción fotográfica de la realidad para centrarse en algo que, a su juicio, resulta mucho más interesante; a saber, la psicología humana: "The novelists in future will realise more and more the importance of these reflections, for of course there is no one reflection but an almost infinite number; those are the depths they will explore, those the phantoms they will pursue" (1985: 85-86). El mundo exterior de los objetos debe, según el narrador, quedar progresivamente fuera de la ficción, para centrarse en un movimiento centrífugo de exploración y conocimiento:

I want to think quietly, calmly, spaciously, never to be interrupted, never to have to raise from my chair, to slip easily from one thing to another, without any sense of hostility, or obstacle. I want to sink deeper and deeper, away from the surface, with its hard, separate facts. (1985: 85)

Finalmente, el narrador sí es interrumpido por un acompañante masculino, quien la devuelve al mundo de los hechos y le recuerda que la marca en la pared es tan sólo un caracol. Y de nuevo, resulta significativo que el flujo de conciencia del narrador - que se articula sin embargo en torno a la misma idea de exclusión y crítica a la misma - sea interrumpido por un hombre, que aplasta la corriente de esa "pleasant track of thoughts" para recordarle el sólido mundo de la superficie, asolado por la guerra que - como Woolf arguye en Three Guineas - es exclusivamente producto del rígido orden social masculino: “'I'm going out to buy a newspaper.' ... 'Though it's no good buying newspapers ... Nothing ever happens. Curse this war! God damn this war! ... All the same, I don't see why we should have a snail on our wall" (1985: 87).

A pesar de todo - y muy al contrario de lo que piensa el personaje masculino - muchas cosas suceden, y el mundo de libertad "intoxicadora" y vivificante que describe el narrador femenino de "The mark on the wall" presenta un modelo de resistencia ideológica frente a un severo orden preestablecido. A la vez, el relato mismo supone la emancipación de Virginia Woolf frente a lo que ella consideraba la "tiranía" del editor y de la política de mercado que le rodea, aunque también - y como consecuencia de ello - la libertad literaria frente al realismo burgués dominante en la literatura de principios del siglo XX que la fundación de The Hogarth Press le permitió.

La abundancia de metáforas y lenguaje emancipador en este relato tan innovador apunta a la expresión de contradicciones, fantasías y deseos que el realismo - a través de la 
rigidez de sus convenciones - silencia. Por otro lado, el relato entronca con toda una tradición de mujeres escritoras que hicieron de este género un "jardín tranquilo y espacioso", cercano a la alegoría, a la fábula, sin duda metáfora liberadora del mundo de la imaginación.

\section{BIBLIOGRAFÍA}

Bacchilega, C. 1996. Postmodern Fairy Tales: Gender and Narrative Strategies. Philadelphia: U. of Pennsylvania P.

Baldwin, D. 1993. "The tardy evolution of the British short story". Studies in Short Fiction 30: 23-33.

Bowen, E. 1976 (1936). "Introduction to The Faber Book of Modern Short Stories". Short Story Theories. Ed. C. May. Athens, Ohio: Ohio 152-158.

Brown, C. \& K. Olson, eds. 1978. Feminist Criticism: Essays on Theory, Poetry and Prose. New Jersey \& London: The Scarecrow P.

Denisoff, D. 1999. "The forest beyond the frame: picturing women's desire in Vernon Lee and Virginia Woolf". Women and British Aestheticism. Eds. T. Schaffer \& K. A. Psomiades. Charlottesville \& London: U. of Virginia P. 251-269.

Eagleton, M. 1989. "Gender and genre". Re-Reading the Short Story. Ed. C. Hanson. London: MacMillan. 55-68.

Ferguson, S. 1989. "The rise of the short story in the hierarchy of genres". Short Story Theory at a Crossroads. Eds. S. Lohafer \& J. E. Clarey. Baton Rouge \& London: Louisiana State U.P. 176-192.

Gillespie, D. 1988. The Sister's Arts: The Writing and Painting of Virginia Woolf and Vanessa Bell. Syracuse, New Jersey: Syracuse U.P.

Gordimer, N. 1968. "The flash of fireflies". Kenyon Review 30: 457-461.

Hanson, C., ed. 1989. Re-Reading the Short Story. London: McMillan.

Harris, W. 1994. "Vision and form: the English novel and the emergence of the short story". The New Short Story Theories. Ed. C. May. Athens, Ohio: Ohio U.P. 182-191.

Head, D. 1992. The Modernist Short Story: A Study in Theory and Practice. Cambridge: C.U.P.

Heilbrun, C. \& M. Higonnet, eds. 1983. The Representation of Women in Fiction. Baltimore \& London: The John Hopkins U.P.

Jackson, R. 1981. Fantasy: The Literature of Subversion. London: Methuen.

Lee, H. 1995. The Secret Self: A Century of Short Stories by Women. London: Virago.

Lukács, G. 1971. The Theory of the Novel: A Historico-Philosophical Essay on the Forms of the Great Epic Literature. Trad. A. Bostock. Cambridge, Massachusetts: MIT P.

Marcus, L. 1996. "Virginia Woolf and the Hogarth Press". Modernist Writers and the Marketplace. Eds. I. Willison et al. London: MacMillan. 124-150.

Moers, E. 1978. Literary Women. London: The Women's P. 
O'Connor, F. 1963. The Lonely Voice: A Study of the Short Story. Cleveland: The World Publishing Co.

Pater, W. 1986 (1873). The Renaissance: Studies in Art and Poetry. Oxford: World's Classics.

Scholes, R. 1979. Fabulation and Metafiction. Urbana \& Chicago: U. of Illinois P.

Shaw, V. 1983. The Short Story: A Critical Introduction. London: MacMillan.

Warner, M. 1995. From the Beast to the Blonde: On Fairy Tales and Their Tellers. London: Chatto \& Windus.

Watt, I. 1957. The Rise of the Novel: Studies in Defoe, Richardson and Fielding. Berkeley \& Los Angeles: U. of California P.

Welty, E. 1949. "The reading and writing of short stories". The Atlantic Monthly 183: 54-58.

Willis, J. H. 1992. Leonard and Virginia Woolf as Publishers: The Hogarth Press 19171941. Charlottesville \& London: University Press of Virginia.

Woolf, L. 1964. Beginning Again: An Autobiography of the Years 1911 - 1918. London: The Hogarth P.

Woolf, V. 1976a. The Letters of Virginia Woolf II. Ed. N. Nicolson. London: The Hogarth P.

1976b. Moments of Being: Unpublished Autobiographical Writings. Ed. J. Schulkind. New York \& London: Harcourt Brace.

Penguin.

1978. The Diary of Virginia Woolf II. Ed. A. O. Bell. Harmondsworth: Penguin.

1980. The Diary of Virginia Woolf III. Ed. A. O. Bell. Harmondsworth: . 1985. The Complete Shorter Fiction of Virginia Woolf. Ed. S. Dick. London: The Hogarth P.

Hogarth P.

1987. The Essays of Virginia Woolf II. Ed. A. McNeillie. London: The . 1988. The Essays of Virginia Woolf III. Ed. A. McNeillie. London: The Hogarth P. 1992 (1929). A Room of One's Own. Oxford: World's Classics.

. 1993. The Selected Essays of Virginia Woolf II. Ed. R. Bowlby.

Harmondsworth: Penguin. Hogarth P. 1994a. The Essays of Virginia Woolf IV. Ed. A. McNeillie. London: The Hogarth P. 1994b. The Letters of Virginia Woolf IV. Ed. N. Nicolson. London: The 